\title{
Correction to: When left does not seem right: epigenetic and bioelectric differences between left and right-sided breast cancer
}

\author{
Sofia Masuelli ${ }^{1,2}$, Sebastian Real ${ }^{1,2}$, Emanuel Campoy ${ }^{1,2}$, Maria Teresita Branham 1,3, Diego Matias Marzese ${ }^{4}$,
} Matthew Salomon ${ }^{5}$, Gerardo De Blas ${ }^{1,2}$, Rodolfo Arias $^{1}$, Michael Levin ${ }^{6}$ and Maria Roque ${ }^{1,7^{*}}$ (D)

\section{Correction to: Molecular Medicine (2022) 28:15} https://doi.org/10.1186/s10020-022-00440-5

Following publication of the original article (Masuelli et al. 2022), we have been informed that first name and last name have been swapped for 1st, 2nd, 3rd, 6th, 8th, 9th and 10th author.

The author group has been updated above and the original article has been corrected.

\section{Author details}

${ }^{1}$ National Council of Scientific and Technological Research (IHEM-CONICET), PC:5500 Mendoza, Argentina. ${ }^{2}$ Medical School, National University of Cuyo, PC:5500 Mendoza, Argentina. ${ }^{3}$ Medical School, Mendoza University, PC:5500 Mendoza, Argentina. ${ }^{4}$ Cancer Epigenetics Laboratory, Health Research Institute of the Balearic Islands (IdISBa), Palma, Spain. ${ }^{5}$ Department of Medicine, Keck School of Medicine, University of Southern California, Los Angeles, CA 90007, USA. ${ }^{6}$ Allen Discovery Center at Tufts University, Medford, MA 02115, USA. ${ }^{7}$ Exact Science Faculty, National University of Cuyo, PC:5500 Mendoza, Argentina.

Published online: 28 February 2022

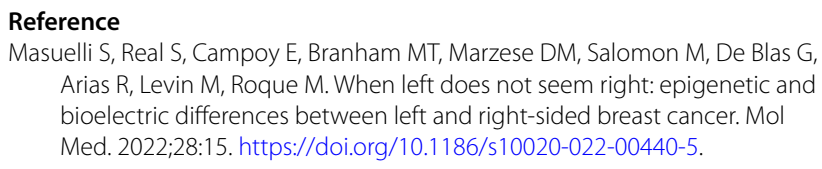

Masuelli S, Real S, Campoy E, Branham MT, Marzese DM, Salomon M, De Blas G, Arias $R$, Levin $M$, Roque $M$. When left does not seem right: epigenetic and bioelectric differences between left and right-sided breast cancer. Mol Med. 2022;28:15. https://doi.org/10.1186/s10020-022-00440-5.

\section{Publisher's Note}

Springer Nature remains neutral with regard to jurisdictional claims in published maps and institutional affiliations. original author(s) and the source, provide a link to the Creative Commons licence, and indicate if changes were made. The images or other third party material in this article are included in the article's Creative Commons licence, unless indicated otherwise in a credit line to the material. If material is not included in the article's Creative Commons licence and your intended use is not permitted by statutory regulation or exceeds the permitted use, you will need to obtain permission directly from the copyright holder. To view a copy of this licence, visit http://creativecommons.org/licenses/by/4.0/. 